\title{
MANAJEMEN RISIKO GADAI EMAS PADA PT.PEGADAIAN SYARIAH JAYAPURA
}

\author{
(Studi Kasus PT.Pegadaian Syariah Unit Pelayanan Syariah Heram) \\ Yunita Sari \\ Institut Agama Islam Negeri (IAIN) Fattahul Muluk Papua \\ E-mail: yutsayun13des19@gmail.com \\ Syaiful Muhyidin \\ Institut Agama Islam Negeri (IAIN) Fattahul Muluk Papua \\ E-mail: syaifulmuhyidin@gmail.com \\ Fachrudin Fiqri Affandy \\ Institut Agama Islam Negeri (IAIN) Fattahul Muluk Papua \\ E-mail: affandyjo@gmail.com
}

\begin{abstract}
The background of this research is the high level of public interest in product of sharia gold pawn so that the risk management is the main focus to be carried out. The most common risk is the risk of loans, especially gold pawn loans. The risk of goal pawn loans becomes the main focus on the Islamic Pawnshop. This is based on the limitations of employees of PT. Pegadaian Syariah Jayapura, especially UPS Heram, in screening data for funding applications. These limitations lead to several stages of loans that are not intentionally or deliberately by passed to accelerate the loans process.

This research used qualitative approach with the case study method. It used primary and supporting data. The information from primary data sources in qualitative research can generally be explored through observation and interview techniques.

This research shows that PT. Jayapura Syariah Pegadaian (UPS) Heram in managing gold pawning risk can be from the risk management process, namely risk identification, risk measurement, and risk management. The mitigation of gold pawn transactions include the risk mitigation of the accuracy of the gold assessment, the risk mitigation of a decline in the price of gold, the risk mitigation of storing gold. The minimizing of the risks that might occur use monitoring, guidance and supervision of internal risks.
\end{abstract}

Keywords: The risk management, gold pawn, PT. Pegadaian Syariah Jayapura UPS Heram. 


\begin{abstract}
ABSTRAK
Latar belakang dari penelitian didasari pada tingkat minat masyarakat yang tinggi pada produk gadai emas syariah sehingga manajemen risiko menjadi focus utama untuk dilakukan. Risiko yang paling sering terjadi yaitu risiko pada pembiayaan khususnya pembiayaan gadai emas. Risiko pembiayaan gadai emas ini menjadi focus utama pada PT. Pegadaian Syariah Jayapura khususnya UPS Heram dalam melakukan screening (penyaringan) data atas pengajuan pembiayaan. Keterbatasan tersebut mengakibatkan adanya beberapa tahapan pembiayaan yang tidak sengaja atau sengaja dilewati untuk mempercepat proses pembiayaan.

Pendekatan yang digunakan adalah kualitatif dengan metode studi kasus. Penelitian ini menggunakan data primer (utama) dan sekunder (penunjang). Informasi dari sumber data primer dalam penelitian kualitatif pada umumnya dapat digali dengan lebih mendalam melalui teknik observasi dan wawancara.

Hasil penelitian dapat disimpulkan PT. Pegadaian Syariah Jayapura (UPS) Heram dalam memanajmen risiko gadai emas dapat dari proses manajemen risiko yaitu, identifikasi risiko, pengukuran risiko, pemantauan risiko, serta pengelolaan risiko. Dalam memitigasi khususnya untuk transaksi gadai emas yaitu, meliputi mitigasi risiko keakuratan penaksiran emas, mitigasi risiko penurunan harga emas, mitigasi risiko penyimpanan emas. Serta meminimalisasikan risiko yang mungkin saja terjadi yaitu dengan melakukan pemantauan, pembinaan serta pengawasan risiko internal.
\end{abstract}

Kata Kunci: Manajemen risiko gadai emas PT. Pegadaian Syariah Jayapura (UPS) Heram.

\title{
PENDAHULUAN
}

Salah satu produk lembaga keuangan Syariah (LKS) yaitu gadai syariah. Gadai dalam syariah atau yang biasa disebut rahn dalam Islam, yang berarti tetap, kekal, dan jaminan. Secara syara, rahn adalah mengambil sejumlah harta yang diserahkan sebagai jaminan secara hak, tapi dapat diambil lagi. Gadai sebagai salah satu kategori dari perjanjian utang-piutang, untuk meyakinkan kepercayaan kreditur, maka debitur menggadaikan barangnya sebagai jaminan terhadap utangnya itu. Barang jaminan tetap milik orang yang menggadaikan, akan tetapi dipegang oleh penerima gadai. Secara teknis operasional dapat dilakukan oleh suatu lembaga keungan syariah, yaitu pegadaian syariah, baik sebagai lembaga swasta maupun pemerintah (Surepno, 2018:175).

Pegadaian syariah adalah salah satu dari lembaga keuangan yang usahanya berpedoman pada prinsip syariah dengan cara menyalurkan pembiayaan dalam bentuk pemberian uang sebagai pinjaman kepada masyarakat, dan untuk suatu kepercayaan dari orang yang berpiutang, maka orang yang berutang memberikan jaminan atas utangnya (Surepno, 2018:175). Jenis Gadai di PT. Pegadaian Syariah bermacam-macam, salah satunya adalah gadai emas, dimana pihak yang membutuhkan pinjaman menyerahkan 
barang jaminannya berupa emas kepada pihak yang memberi pinjaman dan sewaktu-waktu akan dikembalikan jika telah melunasi utang pinjamannya sesuai dengan ketentuan syariah yang ada di PT. Pegadaian syariah.

Secara umum, operasional gadai emas syariah mirip dengan jasa konvensional, yaitu menggadaikan barang untuk memperoleh jaminan uang dalam jumlah tertentu. Untuk jasa ini dalam konvensional dikenakan beban bunga, Sementara dalam gadai emas syariah, nasabah tidak dikenakan bunga tetap yang tetapi yang dipungut dari nasabah adalah biaya penitipa, pemeliharaan, penjagaan serta penaksiran barang yang digadaikan. Perbedaan antara biaya gadai emas syariah dan bunga pegadaian konvensional yaitu dari sifat bunga yang bisa berakumulasi dan berlipat ganda, sementara biaya gadai emas syariah hanya satu kali dan ditetapkan dimuka (Surepno, 2018:175).

PT. Pegadaian Syariah Jayapura khususnya UPS Heram menggunakan prinsip qard, prinsip rahn dan prinsip ijarah. selain itu, ada hal-hal yang harus dipenuhi oleh nasabah dalam pengajuan pembiayaan gadai emas. Terkait dalam pembiayaan gadai emas ini memiliki prosedur atau tahapan dalam pelaksanaannya. Prosedur adalah urutan kegiatan atas suatu transaksi yang dilakukan secara berulang-ulang. Prosedur pembiayaan gadai emas syariah ini memiliki kemungkinan risiko yang bisa saja terjadi baik sengaja atau tidak sengaja, baik itu timbul dari pihak internal (PT. Pegadaian Syariah) dan mungkin saja risiko timbul dari pihak eksternal (nasabah atau pihak lainnya yang berkaitan). Terkait emas adalah barang yang berharga serta mempunyai nilai jual dan nilai beli sampai kapanpun, peraturan tentang adanya manajemen risiko terhadap pembiayaan gadai emas, dimana manajemen risiko merupakan bagian dari kegiatan operasional suatu perusahaan (Wawancara Pribadi, 2019 september 12).

Risiko yang paling sering terjadi yaitu risiko pada pembiayaan khususnya pembiayaan gadai emas. Risiko pembiayaan gadai emas ini menjadi fokus utama pada PT. Pegadaian Syariah. Hal ini karena keterbatasan karyawan pada PT. Pegadaian Syariah Jayapura khususnya Unit Pelayanan Syariah (UPS) Heram dalam melakukan penyaringan data atas pengajuan gadai emas. Keterbatasan ini mengakibatkan adanya beberapa prosedur pembiayaan yang tidak sengaja atau sengaja dilewati untuk percepat prsoes pembiayaan gadai emas. Selain itu, Mitigasi risiko menjadi hal penting karena akan mempengaruhi pencapaian tujuan PT. Pegadaian syariah (UPS) Heram tersebut. Adapun Tujuan PT. Pegadaian syariah adalah pencapaian maslahah. Maslahah dapat dijabarkan dengan dicapainya kesejahteraan umat. Jika risiko tidak dapat dimitigasi dengan baik, akan berimbas pada kesejahteraan masyarakat. Risiko yang muncul jika mitigasi risiko tidak berjalan dengan baik, seperti adanya pembiayaan yang sebenarnya tidak layak diberikan tetapi dianggap layak untuk mendapat pembiayaan, dampaknya akan muncul pembiayaan gadai emas yang bermasalah pada PT. Pegadaian Syariah Jayapura (UPS) Heram (Wawancara Pribadi, 2019 september 12). 
Terdapat Kasus yang pernah terjadi di tempat penelitian yaitu di PT. Pegadaian Syariah Jayapura UPS Heram, terdapat kejadian bahwa nasabah menggadaikan emas palsu dalam jumlah banyak, pengelola menaksir barang gadaian tersebut tanpa mengujinya terlebih dahulu apakah itu emas palsu atau asli. Setelah barang gadaian di simpan diberangkas sudah cukup lama, barulah diketahui pada saat diperiksa barang tersebut merupakan barang gadai palsu atau emas palsu, sehingga menyebabkan pihak pengelola yang bertugas harus mengganti rugi sesuai dengan besaran pinjaman yang telah diberikan kepada si nasabah yang menggadai emas palsu tersebut (Wawancara Pribadi, 2019 september 12).

Selain kasus di atas, tidak menutup kemungkinan akan ada risiko-risiko lain yang muncul pada PT. Pegadaian Syariah Jayapura (UPS) Heram khususnya pada gadai emas, yakni meliputi Risiko Terhadap Barang Jaminan. Situasi politik dan kondisi ekonomi yang berubah-ubah bisa merubah tingkah laku nasabah, karyawan, ataupun masyarakat, jadi mereka terpaksa melakukan tindakan kriminal terhadap barang jaminan atau emas tersebut, seperti pencurian, gadai fiktif, numpang gadai. Atau risiko lain seperti risiko gagal bayar atau macet, juga risiko penurunan harga emas (Wawancara Pribadi, 2019 september 12). Hal ini sudah jelas bahwa implementasi manajemen risiko terhadap barang gadai emas sangat diperlukan, dan untuk mencegah risiko-risiko lain yang mungkin saja akan muncul khususnya pada gadai emas perlu adanya mitigasi risiko dan juga untuk meminimalisasikan risiko pada gadai emas. Dengan itu peneliti ingin mengangkat judul "Manajemen Risiko Gadai Emas Pada PT. Pegadaian Syariah Jayapura (UPS) Heram”.

\section{KAJIAN LITERATUR}

\section{Risiko}

Menurut Idroes, risiko merupakan bahaya atau ancaman atau kemungkinan tindakan yang menimbulkan dampak yang berlawanan dengan tujuan yang ingin dicapai. Risiko merupakan peluang untuk mencapai tujuannya apabila menerapkan konsep manajemen risiko yang sesuai dengan kebutuhan (Idroes Feri.N, 2008:4). Adapun Jenis-jenis resiko umum sebagai berikut:

1. Risiko Kredit

Risiko kredit adalah risiko akibat kegagalan nasabah atau pihak lain dalam memenuhi kewajiban kepada perusahaan sesuai dengan perjanjian yang disepakati.

2. Risiko likuiditas

Risiko Likuiditas adalah risiko akibat ketidakmampuan perusahaan untuk memenuhi kewajiban yang jatuh tempo dari sumber pendanaan arus kas dan/atau aset likuid berkualitas tinggi yang dapat digunakan, tanpa mengganggu aktivitas dan kondisi keuangan (Ari Kristin Prasetyoningrum, 2015:46). 


\section{Risiko OperasionaI}

Risiko yang disebabkan karena tidak cukupnya atau kurang berfungsinya proses internal, atau adanya kesalahan penyalahgunaan wewenang oIeh pegawai, kegagalan sistem, bencana alam dan masalah eksternal Iainnya yang bisa mempengaruhi operasional perusahaan.

4. Risiko Bisnis

Risiko bisnis yaitu risiko yang berhubungan dengan posisi kompetitif dan prospek perusahaan untuk berhasil dalam pasar yang terus berubah.

5. Risiko Hukum

Risiko hukum yaitu Risiko yang timbul akibat dari lemahnya aspek yuridis yang bisa menimbulkan kerugian bagi perusahaan antara lain, disebabkan adanya tuntutan hukum, tiadanya undang undang yang mendukung.

6. Risiko Pasar

Risiko pasar yaitu risiko disebabkan karena terjadi pergerakan variabel pasar, seperti pergerakan nilai agunan terutama Pergerakan harga emas dan gejolak pasar.

7. Risiko Reputasi

Risiko reputasi yaitu risiko yang disebabkan adanya publikasi negatif terkait dengan kegiatan usaha perusahaan atau presepsi negatif terhadap perusahaan (Dokumen Pegadaian, 2015). Risiko reputasi juga adalah risiko kerusakan potensial sebagai akibat opini negatif publik terhadap kegiatan perusahaan sehingga mengalami penurunan jumlah nasabah atau menimbulkan biaya besar karena gugatan pengadilan atau penurunan pendapatan (Imam Al-Ghozali, 2017:17).

\section{Manajemen}

Menurut Soebagio, Manajemen adalah suatu usaha melalui perencanaan, pengorganisasian, pengkoordinasian, dan pengendalian sumber-sumber tenaga manusia dan bahan, untuk mencapai tujuan yang telah ditentukan. Berdasarkan beberapa definisi manajemen tersebut, dapat ditarik kesimpulan bahwa manajemen merupakan suatu perangkat dan proses perencanaan, pengorganisasian, pengkoordinasian, dan pengendalian usaha baik dari pemimpin sampai anggota organisasi serta penggunaan semua sumber daya oleh organisasi, perusahaan, keluarga, dan masyarakat. Jadi mencakup kegiatan merencanakan, mengorganisir, menyusun, memimpin/mengkordinir dan mengawasi penanggulangan risiko. Manajemen resiko merupakan rangkaian prosedur dan metodologi yang digunakan untuk mengidentifikasi, mengukur, memantau, dan mengendalikan resiko yang timbul dari kegiatan usaha (Ahmad Mukhlisin,2018:260). Proses Manajemen Risiko:

1. Identifikasi Risiko

Proses ini merupakan langkah awal dalam memulai identifikasi dengan melakukan analisis pada karakteristik risiko yang melekat pada aktivitas fungsional dan 
juga risiko dari produkdan kegiatan usaha. Salah satu aspek penting dalam identifikasi risiko adalah membuat daftar risiko yang mungkin terjadi sebanyak mungkin serta menganalisisnya secara aktif agar tidak timbul risiko yang berlebihan (Adhiwarman A.Karim, 2011:260).

2. Pengukuran Risiko

Setelah melakukan identifikasi risiko, tahap selanjutnya adalah pengukuran risiko, pengukuran risiko dibutuhkan sebagai dasar (tolok ukur) dari akibat (kerugian) yang akan ditimbulkan oleh suatu risiko (Veithzal Rivai dan Rifki Ismal, 2013:133).

3. Pemantauan Risiko

Pada tahapan ini dilakukan dengan cara mengevaluasi pengukuran risiko yang terdapat pada kegiatan usaha mana yang membutuhkan pengamatan lebih dilihat dari keseringan munculnya risiko tersebut.

4. Pengendalian Risiko

Tahap ini dilakukan untuk melihat kemungkinan penyempurnaan tahap analisis risiko yang diakibatkan oleh perubahan lingkungan. Pengendalian risiko dilakukan atas dasar hasil evaluasi pengukuran risiko yang terdapat pada seluruh produk dan aktivitas perusahaan. Metode pengendalian risiko harus mempertimbangkan analisis terhadap besarnya potensi kerugian serta pertimbangan atas manfaat yang didapat serta biaya yang dikeluarkan (Veithzal Rivai dan Rifki Ismal, 2013:272). Dalam manajemen risiko, ada beberapa hal yang dapat dilakukan dalam pengendalian risiko-risiko, dengan cara, Dihindari, dikurangi dengan mentransfer ke pihak lain, menerima dan melakukan modifikasi, serta menerima namun tidak melakukan modifikasi (Hermawan Darmawi, 2008:21).

\section{Manajemen Risiko Dalam Perspektif Islam}

Keuntungan hanya bisa diakui kehalalannya bila disertai dengan adanya risiko, usaha dan kewajiban yang dilakukan. Risiko merupakan fitrah dalam berbisnis, karena tidak ada satupun dari pihak yang terlibat dalam bisnis mengetahui apakah usaha tersebut akan mendatangkan keuntungan atau kerugian. Hal tersebut sesuai dengan Firman Allah dalam QS. Luqman ayat 34 yang artinya:

"Sesungguhnya Allah, hanya pada sisi-Nya sajalah pengetahuan tentang Hari Kiamat; dan Dialah Yang menurunkan hujan, dan mengetahui apa yang ada dalam rahim. Dan tiada seorangpun yang dapat mengetahui (dengan pasti) apa yang akan diusahakannya besok. Dan tiada seorangpun yang dapat mengetahui di bumi mana dia akan mati. Sesungguhnya Allah Maha Mengetahui lagi Maha Mengenal.” (Qs. Luqman 31:34).

\section{Mitigasi Risiko}

Menurut Darmawi Mitigasi adalah mengurangi frekuensi, besarnya sebuah risiko, atau meminimalisasi dampak potensial dari risiko (Hermawan Darmawi, 2008:43). Proses 
mitigasi risiko merupakan penyusunan berbagai pilihan dan aksi digunakan untuk menetralisasi, mengurangi, atau menghilangkan kerugian yang mungkin ditimbulkan dari suatu risiko (Imam Wahyudi, 2013:75).

\section{Pegadaian Syariah}

Pegadaian merupakan lembaga pembiayaan atau perkreditan dengan sistem gadai, merupakan salah satu perusahaan dibawah naungan Kementrian BUMN, tugas pokoknya adalah membantu kebutuhan dana masyarakat dengan memberikan uang pinjaman berdasarkan hukum gadai. Bersamaan dengan berkembangnya produk syariah di Indonesia, Pada tahun 2003 PT. pegadaian juga mendirikan pegadaian syariah dengan membentuk Unit Layanan Gadai Syariah (ULGS), yang dalam pelaksanaannya berpegang kepada prinsip syariah. Hingga kini Pegadaian Syariah masih menginduk pada PT. Pegadaian dan direncanakan spin off pada tahun 2019.

Konsep operasi pegadaian syariah mengacu pada sistem administrasi modern dengan asas rasionalitas, efesiensi, dan efektivitas dengan nilai Islam. Fungsi operasi pegadaian syariah dijalankan di kantor-kantor cabang pegadaian syariah atau ULGS sebagai satu unit organisasi di bawah binaan Divisi Usaha Lain PT. Pegadaian, dan merupakan unit bisnis mandiri yang secara terstruktur terpisah dari usaha gadai konvensional. Unit Usaha Pelayanan Syariah cabang Dewi Sartika di Jakarta adalah pegadaian syariah pertama, Pada Januari tahun 2003. Dan selanjutnya pendirian ULGS di Surabaya, Makasar, Semarang, Surakarta dan Yogyakarta hingga bulan September 2003, di tahun yang sama pula, 4 kantor cabang pegadaian di Aceh di konversi menjadi kantor Pegadaian Syariah (Luluk Wahyu Rofico, 2018:33).

\section{Gadai Emas}

Gadai Emas Syariah merupakan barang jaminan berupa emas yang diberikan atau digadaikan kepada pihak lembaga keuangan baik bank atau pegadaian syariah untuk mendapatkan dana pinjaman. Prinsip Gadai Emas Syariah memungut biaya yaitu biaya penitipan, pemeliharaan, penjagaan, dan penaksiran. Biaya dihitung berdasarkan harga taksiran. Gadai Emas Syariah berbeda dengan gadai emas konvensional dalam pengenaan biaya. Pegadaian konvensional memungut biaya dalam bentuk bunga yang bersifat akumulatif dan berlipat ganda, jika di Pegadaian Syariah dan/atau bank syariah yang tidak berbentuk bunga, tetapi berupa biaya penitipan, pemeliharaan, penjagaan, dan penaksiran (Laily Nurhayati, 2016:77).

\section{METODE PENELITIAN}

Penelitian ini adalah penelitian kualitatif. Menurut Moleong Penelitiam kualitatif adalah penelitian yang bermaksud untuk memahami fenomena tentang apa yang dialami oleh subjek penelitian misalnya seperti perilaku, Presepsi, Motivasi, Tindakan dll. Secara 
Holistik dan dengan cara deskripsi dalam bentuk kata-kata dan bahasa, pada suatu konteks khusus yang alamiah dan dengan memanfaatkan berbagai metode alamiah (Enny Radjab dan Andi Jam'an, 2010:12). Lokasi penelitian dalam proposal ini adalah di PT.Pegadaian Syariah Jayapura UPS Heram yang bertempat di perumnas 2 waena. PT Pegadaian Syariah di perumnas 2 ini merupan Unit Pembantu dari PT. Pegadaian Syariah cabang yang teletak di Jayapura. Adapun kriteria dan informan yang ditunjuk atau dipilih dalam penelitian ini adalah informan yang berhubungan langsung dengan pihak PT. Pegadaian Syariah Jayapura UPS Heram bagian pengelola UPS Heram, dimana informan mengetahui mengenai PT. Pegadaian Syariah Jayapura UPS Heram khususnya mengenai manajemen risiko gadai emas yang ada di PT. Pegadaian Syariah Jayapura UPS Heram.

Pengumpulan data dengan teknik observasi dan wawancara merupakan cara yang utama sekaligus sebagai penciri utama bagi penelitian kualitatif. Dalam hal ini wawancara ditujukan kepada Kepala cabang PT. Pegadaian Syariah Jayapura dan pihak Pengelola PT. Pegadaian Syariah UPS Heram yang mengetahui bagaimana implementasi manajemen risiko gadai emas serta mitigasi risiko yang dilakukan untuk meminimalisir risiko gadai emas pada PT. Pegadaian Syariah Jayapura UPS Heram. Wawancara dilakukan dengan pertanyaan yang terus berkembang tetapi tetap fokus dan mengarah pada topik penelitian. Hasil observasi dan wawncara dari obyek penelitian akan didokumentasikan. Adapun Proses analisis data dalam penelitian kualitatif dimulai sejak merumuskan dan menjelaskan maslah (Boedi Abdulah, 2014:221).

\section{HASIL DAN PEMBAHASAN \\ Hasil}

Hasil wawancara dengan informan 1 mengenai implementasi manajemen risiko gadai emas pada PT. Pegadaian Syariah Jayapura (UPS) Heram diketahui bahwa Pihak PT. Pegadaian Syariah Jayapura (UPS) Heram dalam mengimplementasikan manajemen risiko khusunya pada gadai emas ada' tiga proses yaitu melalui identifikasi risiko, pengukuran risiko, serta pengelolaan risiko.

a. Identifikasi Risiko

Dalam proses identifikasi pihak PT. Pegadaian Syariah Jayapura (UPS) Heram memfokuskan pada tiga sumber risiko, yaitu dari aspek keamanan penyimpanan, penurunan harga emas, serta keakuratan proses penaksiran dengan melalui uji fisik yaitu, dilihat dari warnanya, uji kimia dengan cara perhiasan digosokkan di atas batu uji menggunakan cairan kimia, uji berat jenis dengan cara perhiasan ditimbang apabila perhiasan itu tidak berongga atau tidak kosong maka akan muncul jumlah karatasenya. Selain identifikasi aspek sumber risiko, ada pula pada saat melakukan identifikasi terdapat beberapa risiko yang diperkirakan mungkin akan terjadi pada PT. Pegadaian 
Syariah Jayapura (UPS) Heram, yaitu risiko operasional gadai emas, risiko likuiditas, serta risiko pasar.

b. Pengukuran Risiko

\begin{tabular}{|c|c|c|}
\hline \multicolumn{2}{|c|}{ Jenis Risiko } & \multirow[b]{2}{*}{$\begin{array}{l}\text { Keterangan } \\
\text { Kasus pencurian bisa saja terjadi baik dari pihak internal } \\
\text { maupun eksternal dapat diukur dari kerugian yang } \\
\text { ditimbulkan, terkait emas merupakan barang yang memiliki } \\
\text { nilai jual dan nilai beli sampai kapanpun. Jika terjadi } \\
\text { pencurian dari internal akan sangat merugikan pihak PT. } \\
\text { Pegadaian Syariah Jayapura (UPS) Heram karena tidak } \\
\text { hanya kerugian finansial tetapi juga mencemari nama baik } \\
\text { perusahaa jadi berpengaruh pada reputasi perusahaan dari } \\
\text { sini bisa timbul lagi risiko reputasi. Sehingga risiko ini } \\
\text { digolongkan dalam golongan risiko yang sangat berbahaya } \\
\text { karena kerugian yang ditimbulkan sangat besar. Namun } \\
\text { Untuk saat ini kasus pencurian belum pernah terjadi di PT. } \\
\text { Pegadaian Syariah Jayapura (UPS) Heram. }\end{array}$} \\
\hline \multirow{4}{*}{ Risiko Operasional Gadai Emas } & Pencurian & \\
\hline & Gadai Fiktif & $\begin{array}{l}\text { kasus gadai fiktif ini telah terjadi pada PT. Pegadaian } \\
\text { Syariah Jayapura (UPS) Heram, dan kerugian yang } \\
\text { ditimbulkan juga besar karena kelalaian dari pegawainya } \\
\text { sehingga harus diganti rugi sebesar nilai gadai fiktif } \\
\text { tersebut. Hal ini tergantung besaran nilai dari barang } \\
\text { gadaian, apabila barang gadaian fiktif itu dalam jumlah } \\
\text { banyak yang mencapai puluhan juta maka akan sangat } \\
\text { merugikan pihak perusahaan. Sehingga risiko ini tergolong } \\
\text { risiko yang besar karena menyangkut finansial dan } \\
\text { kepercayaan pihak perusahaan kepada pegawai. }\end{array}$ \\
\hline & Numpang Gadai & $\begin{array}{l}\text { Kasus ini belum pernah terjadi, akan tetapi tergolong dalam } \\
\text { risiko yang berbahaya karena merugikan pihak nasabah, } \\
\text { dampaknya bisa meimbulkan risiko baru untuk muncul yaitu } \\
\text { risiko reputasi. Dimana Pihak PT. Pegadaian Syariah } \\
\text { Jayapura (UPS) Heram akan kehilangan kepercayaan dari } \\
\text { nasabah, akibat kesengajaan menggadai dengan } \\
\text { mengatasnamakan nasabah. }\end{array}$ \\
\hline & Kesalahan Penaksiran & $\begin{array}{l}\text { Untuk kasus ini, pernah terjadi akan tetapi kerugian yang } \\
\text { ditimbulkan tidak begitu parah, karena bisa dilakukan } \\
\text { penaksiran ulang barang gadaian sehingga masih dapat } \\
\text { diatasi dengan segera. Hanya saja jika terjadi kesalahan } \\
\text { penaksiran secara terus menerus itu akan berimbas pada } \\
\text { kepercayaan nasabah. sehingga perlu adanya pembinaan } \\
\text { karyawan. }\end{array}$ \\
\hline
\end{tabular}




\begin{tabular}{|c|c|c|}
\hline \multicolumn{2}{|c|}{ Jenis Risiko } & Keterangan \\
\hline Risiko Liquiditas & $\begin{array}{c}\text { Gagal Bayar atau } \\
\text { Macet }\end{array}$ & $\begin{array}{l}\text { Gagal bayar atau macet ini pernah terjadi pada PT. Pegadaian Syariah } \\
\text { Jayapura (UPS) Heram, akan tetapi kerugian yang ditimbulkan tidak } \\
\text { begitu parah karena pihak perusahaan masih bisa mengatasinya dengan } \\
\text { melelang barang jaminan milik nasabah agar dapat mengcover } \\
\text { kegagalan bayar si nasabah, dan jika ada kelebihan akan dikembalikan } \\
\text { kepada nasabah. }\end{array}$ \\
\hline Risiko Pasar & Penurunan Harga Emas & $\begin{array}{l}\text { Penurunan harga emas ini juga sering terjadi pada PT. Pegadaian } \\
\text { Syariah Jayapura (UPS) Heram, akan tetapi risiko yang ditimbulkan } \\
\text { tidak parah karena masih bisa diatasi, walaupun pihak perusahaan } \\
\text { harus menjual emas lelang dibawah harga emas aslinya akan tetapi itu } \\
\text { sudah bisa mengcover gagal bayar nasabah, dan jika belum bisa } \\
\text { tercover sepenuhnya maka pihak perusahaan akan meleburkan barang- } \\
\text { barang gadaian yang telah masuk jadwal lelang untuk dibentuk emas } \\
\text { yang baru agar memiliki nilai jual yang lebih tinggi. }\end{array}$ \\
\hline
\end{tabular}

\section{c. Pemantauan Risiko}

Pihak PT. Pegadaian Syariah Jayapura (UPS) Heram dalam melakukan pemantauan khusus kepada gadai emas ini, yakni dengan memantau perkembangan nasabahnya agar selalu menjalin komunikasi yang baik sehingga tepat waktu dalam membayar pinjamannya pada saat jatuh tempo sehingga tidak menimbulkan gagar bayar atau macet.

d. Pengelolaan Risiko

Pengelolaan Risiko Ada beberapa tahapan yang dilakukan oleh PT. Pegadaian Syariah Jayapura (UPS) Heram untuk mengelola risiko. Dalam mengelola risiko pihak PT. Pegadaian Syariah Jayapura (UPS) Heram melakukannya dengan tiga cara yaitu dengan cara mengindari risiko tersebut, risk avoidance (pehindaran risiko) dengan cara melakukan kontrol terhadap emas yang akan dilakukan secara ketat. Baik itu dari keaslian, ukuran dan dokumen kepemilikan oleh nasabah. Dan tak lupa memberi pelatihan bagi para pegawai. Dikurangi dengan ditransfer ke pihak lain, pengalihan risiko dilakukan apabila pihak PT. Pegadaian Syariah Jayapura (UPS) Heram sendiri tidak mampu mengatasinya yaitu terkait dengan tindakan penyelewengan baik dari pihak PT. Pegadaian Syariah Jayapura (UPS) Heram ataupun dari pihak nasabah yaitu dengan menggunkan jalur hukum. Serta menerima risiko tanpa memodifikasinya dengan cara, Pihak PT. Pegadaian Syariah Jayapura (UPS) Heram melelang barang jaminan nasabah untuk menutupi kegagalan bayar oleh nasabah tersebut dan jika ada sisa atau kelebihan dari lelang tersebut maka akan diberikan kepada pihak nasabah. 
Hasil wawancara dengan informan mengenai Mitigasi Risiko Yang Dilakukan Pihak PT. Pegadaian Syariah Jayapura (UPS) Heram serta cara Meminimalisasikan Risiko Pada Gadai Emas dapat dijabarkan sebagai berikut:

a. Mitigasi risiko keakuratan penaksiran emas

Hasil wawancara dengan informan 2 mengenai Mitigasi risiko keakuratan penaksiran emas dapat dijelaskan bahwa, hal ini harus melalui prosedur yaitu menyerahkan barang jaminan atau barang gadaian terlebih dahulu kemudian diuji menggunakan alat air uji dan batu uji khusus emas.

b. Mitigasi risiko penurunan harga emas

Hasil wawancara dengan informan 3 mengenai Mitigasi risiko penurunan harga emas pada PT. Pegadaian Syariah Jayapura (UPS) Heram dijelaskan bahwa, pihak PT. Pegadaian Syariah Jayapura (UPS) Heram telah menetapkan terlebih dahulu maksimal pembiayaan produk gadai emas syariah yaitu 92\% hingga $97 \%$ dengan maksimal batas waktu gadai emas selama 4 bulan.

c. Mitigasi risiko penyimpanan emas

Hasil wawancara dengan informan 4 mengenai mitigasi risiko penyimpanan emas pada PT. Pegadaian Syariah Jayapura (UPS) Heram dapat dijelaskan sebagai bahwa, pihak PT. Pegadaian Syariah Jayapura (UPS) Heram menyimpan barang gadaian atau barang jaminan berdasarkan nomor urut dan golongan emas tersebut.

d. Mitigasi risiko gagal bayar atau macet yang timbul dari nasabah

Hasil wawancara dengan informan 1 mengenai mitigasi risiko gagal bayar atau macet yang timbul dari nasabah dapat dijelaskan bahwa, Pihak PT. Pegadaian Syariah Jayapura (UPS) Heram mengirim sms kepada nasabah akan jatuh tempo pembayaran, jika tidak ada respon maka dilakukan penelvonan dan jika tidak ada respon maka pihak PT. Pegadaian Syariah Jayapura (UPS) Heram mendatangi nasabah dan memberi pengertian secara kekeluargaan untuk mencari solusinya.

e. Mitigasi Risiko reputasi produk gadai emas

Hasil wawancara dengan informan 1 mengenai mitigasi risiko reputasi produk gadai emas dapat dijelaskan bahwa, Pihak PT. Pegadaian Syariah Jayapura (UPS) Heram melakukan pelatihan bagi para karyawan/ pengurus serta penyuluhan kepada masyarakat mengenai gadai emas pada pada PT. Pegadaian Syariah Jayapura (UPS) Heram dan tidak lupa meyakinkan masyarakat.

Meminilisasikan Risiko Gadai Emas

Hasil wawancara dengan informan 1 dan informan 2 mengenai mitigasi Secara umum upaya-upaya yang telah dilakukan oleh PT. Pegadaian Syariah Jayapura (UPS) Heram dalam meminimalisasikan risiko terhadap produk gadai emas dapat dilakukan dengan beberapa langkah, diantaranya yaitu: 


\section{a. Pemantauan}

pengawasan atau pemantauan dilakukan di dalam kantor yang mekanismenya dilaksanakan oleh manajer di meja penaksir terhadap barang jaminan atau barang gadaian nasabah. Kemudian hasilnya akan dibahas dalam foum pada saat evaluasi pada pertemuan.

b. Pembinaan

Pihak PT. Pegadaian Syariah Jayapura mengadakan diklat kepada para karyawan sehingga lebih teliti dalam bekerja dan dalam engetahui karakter nasabah.

c. Pengawasan Risiko Internal

Sistem pengawasan berbasis risiko yang dilakukan oleh PT. Pegadaian Syariah Jayapura (UPS) Heram, maka risiko-risiko yang terjadi khususnya pada gadai emas ini akan lebih terpantau, sehingga terhindar dari penyelewengan-penyelewengan yang dilakukan dari pegadaian itu sendiri. Selain itu perlu diperhatikan juga, bahwa tingkat keberhasilan akan tercermin dari indikator tingkat kesehatan yang baik dari PT. Pegadaian Syariah Jayapura (UPS) Heram tersebut. Sistem pengawasan dalam kantor itu sendiri, yang mekanisme pengawasannya dilaksanakan oleh manajer cabang atau yang mewakili atau dikuasakan terhadap pelaksanaan pekerjaan aparat cabang dengan mengawasi jenis risiko apa yang perlu dikelola pada lingkungan internal atau didalam area perusahaan.

\section{Pembahasan}

Berdasarkan hasil penelitian mengenai implementasi manajemen risiko pada PT. Pegadaian Syariah Jayapura (UPS) Heram dapat dijelaskan bahwa, PT. Pegadaian Syariah Jayapura (UPS) Heram dalam mengimplementasikan manajemen risiko yaitu dimulai dengan proses manajemen risiko terlebih dahulu yaitu, identifikasi risiko, pengukuran risiko, serta pengelolaan risiko. Proses manajemen risiko yang pertama yaitu pengidentifikasian risiko oleh pihak PT. Pegadaian Syariah Jayapura (UPS) Heram dengan cara memfokuskan pada tiga sumber risiko, yaitu dari aspek keamanan penyimpanan, penurunan harga emas, serta keakuratan proses penaksiran dengan melalui uji fisik yaitu, ditimang dilihat dari warnanya, uji kimia dengan cara perhiasan digosokkan di atas batu uji menggunakan cairan kimia, uji berat jenis dengan cara perhiasan ditimbang apabila perhiasan itu tidak berongga atau tidak kosong maka akan muncul jumlah karatasenya.

Dalam proses identifikasi pihak PT. Pegadaian Syariah Jayapura (UPS) Heram memfokuskan pada tiga sumber risiko, yaitu dari aspek keamanan penyimpanan, penurunan harga emas, serta keakuratan proses penaksiran dengan melalui uji fisik yaitu, dilihat dari warnanya, uji kimia dengan cara perhiasan digosokkan di atas batu uji menggunakan cairan kimia, uji berat jenis dengan cara perhiasan ditimbang apabila perhiasan itu tidak berongga atau tidak kosong maka akan muncul jumlah karatasenya. 
Selain identifikasi aspek sumber risiko, ada pula pada saat melakukan identifikasi terdapat beberapa risiko yang diperkirakan mungkin akan terjadi pada PT. Pegadaian Syariah Jayapura (UPS) Heram, yaitu risiko operasional gadai emas, risiko likuiditas, serta risiko pasar.

Kedua, PT. Pegadaian Syariah Jayapura (UPS) Heram melakukan Pengukuran pada risiko-risiko yang telah diidentifikasi akan muncul dalam gadai emas diukur dengan melihat seberapa parahkah risiko tersebut dilihat dari kerugian yang ditimbulkannya dan seberapa sering terjadinya, Sampai pada tahap proses manajemen risiko yang terakhir yaitu pengeloaan risiko dengan cara mengindari risiko tersebut, dikurangi dengan ditransfer ke pihak lain, serta menerima risiko tanpa memodifikasinya, atau dengan memodifikasinya.

Hal ini sesuai dengan teori :

"Proses manajemen risiko yaitu Identifikasi risiko Proses ini merupakan langkah awal dalam memulai identifikasi dengan melakukan analisis pada karakteristik risiko yang melekat pada aktivitas fungsional dan juga risiko dari produkdan kegiatan usaha. Salah satu aspek penting dalam identifikasi risiko adalah membuat daftar risiko yang mungkin terjadi sebanyak mungkin serta menganalisisnya secara aktif agar tidak timbul risiko yang berlebihan (Adhiwarman A.K, 2011:260). Setelah melakukan identifikasi risiko, tahap selanjutnya adalah pengukuran risiko, pengukuran risiko dibutuhkan sebagai dasar (tolok ukur) dari akibat (kerugian) yang akan ditimbulkan oleh suatu risiko (Veithzal Rivai,dan Rifki Ismal, 2013:133). Adapun pemantauan risiko Pada tahapan ini dilakukan dengan cara mengevaluasi pengukuran risiko yang terdapat pada kegiatan usaha mana yang membutuhkan pengamatan lebih dilihat dari keseringan munculnya risiko tersebut. Selanjutnya ada Tahap ini dilakukan untuk melihat kemungkinan penyempurnaan tahap analisis risiko yang diakibatkan oleh perubahan lingkungan. Pengendalian risiko dilakukan atas dasar hasil evaluasi pengukuran risiko yang terdapat pada seluruh produk dan aktivitas perusahaan. Metode pengendalian risiko harus mempertimbangkan analisis terhadap besarnya potensi kerugian serta pertimbangan atas manfaat yang didapat serta biaya yang dikeluarkan. Dalam manajemen risiko, ada beberapa hal yang dapat dilakukan dalam pengendalian risiko-risiko, dengan cara, Dihindari, dikurangi dengan mentransfer ke pihak lain, menerima dan melakukan modifikasi, serta menerima namun tidak melakukan modifikasi"

Dari hasil penelitian dan landasan teori dapat dilihat bahwa terdapat kecocokan antara keduanya yaitu pada saat peneliti melakukan penelitian pada PT. Pegadaian Syariah Jayapura (UPS) Heram ditemukan bahwa pihak PT. Pegadaian Syariah Jayapura (UPS) Heram mengimplementasikan proses manajemen risiko yaitu dengan cara identifikasi risiko, pengukuran risiko, serta pengelolaan risiko hal ini sama dengan teori yang dipaparkan di atas yang juga mengatakan proses manajemen terdiri atas tiga yaitu identifikasi, pengukuran risiko, serta pengeloaan risiko baik dikelola dengan cara dihindari, 
ditahan ataupun ditransfer, menerima dengan tanpa memodifikasi ataupun menerima dengan memodifikasinya.

Tak hanya megimplementasikan manajemen risiko, pihak PT. Pegadaian Syariah Jayapura (UPS) Herampun telah menyiapkan mitigasi risiko serta cara meminimalisasikan dampak risiko yang menimbulkan kerugian muncul secara tiba-tiba. Pada saat peneliti melakukan observasi kemudian wawancara dengan pihak PT. Pegadaian Syariah Jayapura (UPS) Heram disampaikan bahwa, Sebelum melakukan mitigasi risiko pihak PT. Pegadaian Syariah Jayapura (UPS) Heram harus menganalisis terlebih dahulu risiko yang terjadi, seberapa parahkah agar risiko yang muncul bisa dimitigasi dengan tepat. Pihak PT. Pegadaian Syariah Jayapura (UPS) Heram melakukan mitigasi risiko bertujuan untuk mengatasi, atau mengurangi kerugian yang muncul atau bahkan merupakan tindakan pencegahan agar tidak mendapat kerugian dari risiko yang terjadi. Hal ini sesuai dengan teori:

"Mitigasi adalah eliminasi atau mengurangi frekuensi, besarnya, kerasnya atau eksposure dari sebuah risiko, atau meminimalisasi dampak potensial dari ancaman atau peringatan" (Hermawan Darmawi, 2008:43). "Proses mitigasi risiko merupakan proses penyusunan berbagai pilihan dan aksi yang dapat digunakan untuk menetralisasi, mengurangi, atau menghilangkan kerugian yang mungkin ditimbulkan dari suatu risiko" (Imam Wahyudi, 2013:75).

Berdasarkan hasil temuan, pihak PT. Pegadaian Syariah Jayapura (UPS) Heram melakukan mitigasi risiko serta meminimalisasikan risiko kususnya pada gadai emas yang terdiri dari (1) mitigasi risiko keakuratan penaksiran emas, agar berjalan sesuai dengan prosedur dan tidak terjadi kesalahan penaksiran. (2) Mitigasi risiko penurunan harga emas, dengan menetapkan jumlah biaya serta batas waktu jatuh tempo sehingga sekalipun harga emas lagi naik atau turun tidak akan mempengaruhi apapun. (3) Mitigasi risiko penyimpanan emas, agar tidak terjadi kesalahan operasional pada saat nasabah menebus barang gadaian. Karena, telah diurut berdasarkan nomor urut gadainya. (4) Mitigasi risiko gagal bayar atau macet yang timbul dari nasabah, agar nasabah bisa tepat waktu membayar pinjaman dari total gadaiannya apabila jatuh tempo sehingga tidak menimbulkan gagal bayar yang berujung pada kerugian baik bagi pihak nasabah maupun perusahaan. (5) Mitigasi Risiko reputasi produk gadai emas, agar nama baik peruahaan tetap terjaga dan tidak menimbulkan kerugian yang berujung penurunan tingkat kepercayaan nasabah apabila reputasi perusahaan buruk.

Adapun meminimalisasikan dilakukan, (1) Pemantauan, meminimalisasikan risiko dimeja penaksir apabila terjadi kesalahan pada mekanisme gadai emas. (2) Pembinaan, meminimalisasikan risiko yang disebabkan oleh SDM maka dari itu dibutuhkan pembinaan kepada para karyawan perusahaan. (3) Pengawasan risiko internal, meminimalisasikan 
risiko yang terjadi didalam area perusahaan sehingga terhindar dari penyelewenganpenyelewengan pada PT. Pegadaian Syariah Jayapura (UPS) Heram.

Jika dilihat dari penelitian terdahulu yang peneliti jadikan acuan terdapat satu penelitian terdahulu yang sama-sama menggunakan proses manajemen risiko dalam mengimplementasikan manajemen risiko yang terkait identifikasi, pengukuran serta pengelolaan risiko, akan tetapi implementasi manajemen risiko tersebut pada Bank, sedangkan yang peneliti teliti yaitu khusus pada PT. Pegadaian Syariah yang ada di Jayapura (UPS) Heram. Sedangkan keempat penelitian terdahulu masing-masing memiliki cara yang sama dalam memanajemen risiko gadai emas yaitu dengan meminimalisir risiko tersebut. Begitupun peneliti juga memaparkan mitigasi serta cara meminimalisasikan risiko.

\section{KESIMPULAN DAN SARAN}

\section{Kesimpulan}

Dalam mengimplementasikan manajemen risiko pada PT. Pegadaian Syariah Jayapura (UPS) Heram, dimulai dengan proses manajemen risiko terlebih dahulu yaitu, identifikasi risiko, pengukuran risiko, pemantauan risiko, serta pengelolaan risiko. Risikorisiko yang kemungkinan terjadi pada saat dilakukan identifikasi pada gadai emas di PT. Pegadaian Syariah Jayapura (UPS) Heram yaitu, risiko operasional, risiko likuiditas, dan risiko pasar.

Mitigasi Risiko yang dilakukan pihak PT. Pegadaian Syariah Jayapura (UPS) Heram serta untuk meminimalisasikan risiko pada gadai emas ialah, mitigasi risiko keakuratan penaksiran emas, mitigasi risiko penurunan harga emas, mitigasi risiko penyimpanan emas, Mitigasi risiko gagal bayar atau macet yang timbul dari nasabah, serta mitigasi risiko reputasi gadai emas. Selain mitigasi, pihak PT. Pegadaian Syariah Jayapura (UPS) Heram juga menyiapkan cara untuk meminimalisasikan risiko yang mungkin saja akan terjadi yaitu dengan melakukan pemantauan, pembinaan, serta pengawasan risiko internal.

\section{Saran}

Berkenaan dengan pembahasan dan kesimpulan di atas, maka penulis memberikan saran sebagai berikut:

\section{Bagi Pihak Lembaga}

Pihak PT. Pegadaian Syariah Jayapura (UPS) Heram Berdasarkan manajemen risiko yang telah ditetapkan tersebut haruslah diimplementasikan semaksimal mungkin agar jika risiko-risiko yang telah diperkirakan akan muncul itu terjadi maka pihak PT. Pegadaian Syariah Jayapura (UPS) Heram tidak kewalahan dalam menanganinya. Selain harus mengimplementasikan manajemen risiko dengan maksimal pihak PT. Pegadaian Syariah Jayapura (UPS) Heram harus meminimalisasikan risiko tersebut dengan memperketat pengawasan didalam perusahaan, serta pemantauan secara umum sehingga 
risiko tersebut dapat teratasi. Adapun mitigasi risiko yang harus dipersiapkan oleh pihak PT. Pegadaian Syariah Jayapura (UPS) Heram agar risiko yang berpotensi akan muncul itu tidak akan terjadi.

2. Bagi Pihak Nasabah

Nasabah pada PT. Pegadaian Syariah Jayapura (UPS) Heram harus dapat mematuhi ketentuan yang berlaku pada pegadaian serta ketentuan yang tercantum dalam surat gadai, agar nasabah tidak mengalami kerugian akibat kelalaian yang dilakukan sendiri. Oleh karena itu ketika mau meminjam di pegadaian tentunya harus ada perhitungan mengenai kemampuan membayar angsuran, sehingga barang jaminan tidak sampai dilelang oleh pihak pegadaian.

3. Bagi Peneliti Selanjutnya

Penelitian ini dapat dilakukan kembali dengan objek penelitian yang berbeda dan dikembangkan lagi sehingga lebih banyak ilmu dan manfaat yang di dapat. Bagi peneliti selanjutnya dapat dimanfaatkan sebagai bahan rujukan dalam melakukan penelitian yang berkaitan dengan manajemen risiko gadai emas pada PT. Pegadaian Syariah.

\section{DAFTAR REFERENSI}

\section{Buku}

Abdullah Boedi. (2014). Metodologi Penelitian Ekonomi Islam, Bandung: CV. Pustaka

Setia,

Al-Ghozali Imam. (2017). Manajemen Risiko Perbankan, Semarang: Pusat Penerbit Universitas Diponegoro.

Darmawi Hermawan. (2008). Manajemen Risiko, Jakarta : PT.Bumi Aksara.

Karim A. Adhiwarman. (2011). Bank Islam Analisis Fiqih dan Keuangan, Jakarta: Rajawali Pers

Mukhlisin Ahmad dkk. (2018), “Analisis Manajemen Risiko”, An-Nisbah: Jurnal Ekonomi Syariah, Vol.5,No.1.

N Idroes Feri. (2008). Manajemen Risiko Perbankan: pemahaman pendekatan 3 pilar kesepakatan bassel II terkait aplikasi regulasi dan pelaksanaannya di Indonesia, Jakarta: Rajawali Pers.

Radjab Enny dan Jam'an Andi. (2010). Metodologi Penelitian Bisnis, Makassar: Universitas Muhammadiyah Makassar, Februari.

Rifki Ismal dan Veithzal Rivai. (2013). Islamic Risk Management For Islamic Bank, Jakarta: PT. Gramedia Pustaka.

Wahyudi Imam, dkk. (2013). manajemen risiko bank islam, Jakarta: salemba empat. 


\section{Jurnal}

Nurhayati Laili dkk. (2016), "Pembiayaan Gadai emas Konvensional dan Syariah”, Jurnal Ilmiah Al-Syir'ah, Vol.14,No.2.

Prasetyoningrum Ari Kristin. (2015). Risiko Bank Syariah, Yogyakarta: Pustaka Pelajar,

Rofico Luluk Wahyu. (2018), “Aplikasi Akad Rahn Pada Pegadaian Syariah”, Jurnal Ekonomi dan Perbankan Syariah, Vol.3, No.2.

\section{Dokumen}

Dokumen Pegadaian, 2015

Wawancara

Sifyon, (2018 Agustus 20) Wawancara Pribadi

Dewi, (2019 Oktober 07) Wawancara Pribadi

Odhe, (2019 Oktober 14), Wawancara Pribadi

Opan, (2019 Oktober 14), Wawancara Pribadi 